\title{
Praktek Riba dan Kesenjangan Sosial
}

\author{
Oleh: M. Fajar Hidayanto*
}

\begin{abstract}
That usury is a crime that undermine the essence, the goal of Islam and faith. Lap can also cause destruction Ukhuwah between believers and strife among people. Usury is the attitude of the human exploitation of other human beings. In life today, people are exposed to the condition of Islam which is very difficult, not how close most of the economic activities contain elements of usury. When we are not careful then that will happen is stuck usury.
\end{abstract}

Keywords:

\section{Pendahuluan}

Keadilan sosioekonomi, salah satu karakteristik yang paling menonjol dari sebuah masyarakat muslim ideal, dituntut menjadi sebuah cara hidup dan bukan suatu fenomena terpisah. Ia harus menjangkau semua wilayah interaksi kemanusiaan, sosial, ekonomi, dan politik. Ketidakadilan yang terjadi di suatu wilayah akan berkembang pada wilayah yang lain. Sebuah institusi yang salah pasti akan gagal memberi warna kepada institusi yang lain. Bahkan, dalam dunia bisnis dan ekonomi sekalipun, semua nilai harus menyatu dengan keadilan sehingga dalam keseluruhan totalisasinya akan mendorong, bukannya memadamkan, keadilan sosioekonomi.

Salah satu ajaran Islam yang penting untuk menegakkan keadilan dan menghapuskan eksploitasi dalam transaksi bisnis adalah dengan melarang semua bentuk peningkatan kekayaan "Secara tidak adil". Al-Qur'an dengan tegas melarang kaum muslimin mengambil harta orang lain dengan cara yang batil (bil-bațil) atau dengan cara yang tidak benar ${ }^{1}$.

Al-Qur'an dan As-Sunnah telah memberikan prinsip-prinsip yang dapat diketahui atau dideduksi oleh kaum muslimin mengenai cara-cara memperoleh kekayaan dan penghasilan "yang salah" atau "yang benar" dan "yang diperbolehkan" atau "yang tidak diperbolehkan". Salah satu sumber penting peningkatan kekayaan

* Penulis adalah dosen tetap Program Studi Ekonomi Islam Fakultas Ilmu Agama Islam Universitas Islam Indonesia Yogyakarta. Email: jarhid@plaza.com

${ }^{1}$ QS. Al-Baqarah (2): 188 dan An-Nisaa' (4): 29 
yang tidak diperbolehkan adalah menerima keuntungan moneter dalam sebuah transaksi bisnis tanpa memberikan suatu imbalan setimpal yang adil. Dalam hal ini "riba" mewakili sistem nilai Islam, suatu sumber utama keuntungan yang tidak diperbolehkan itu.

Dalam hal mu'amalah, Islam menawarkan panduan yang jelas dalam setiap transaksi. Semua ketentuan yang ada mempunyai tujuan, untuk menghasilkan transaksi yang halal dan tayyib. Islam juga telah menggariskan jenis-jenis transaksi yang dilarang, seperti; membuat dan menjual barang-barang yang najis, misalnya; bangkai, babi, anjing, arak, kencing, dan lain-lain. Barang-barang tersebut di atas adalah haram li żatibi, karena Rasulullah SAW, bersabda ; "Sesungguhnya Allah SWT. Jika mengharamkan suatu barang maka harganya pun haram juga"2. Barang-barang yang tidak bermanfaat dalam Islam (membawa kepada mafsadat dan maksiat) atau yang mendatangkan kelalaian hingga menyebabkan seseorang individu itu lupa untuk beribadah kepada Allah juga tidak dibenarkan. Transaksi yang mengandung unsur riba, gharar, perjudian bacy' ma'dumc, melakukan penipuan dalam transaksi, membeli di atas belian orang lain, melakukan penimbuhan (ihtikar) dan lain-lain ${ }^{3}$.

Alasan dan landasan normatif yang digunakan ahli figh, dalam hal ini merupakan dasar yang telah ada sejak awal Islam muncul ke permukaan (yaitu pada zaman Rasulullah hidup), sehingga setiap dalil memiliki konteks dengan masyarakat yang hidup di sekitar Nabi pada saat itu. Hal inilah yang sering menjadi bahan perdebatan para ahli yang hidup saat ini. Idealnya, sesuatu yang sesuai dengan konsep pada saat itu tidak sepenuhnya dapat diterapkan pada realita (yang sering bergantung pada kebutuhan) masyarakat yang hidup saat ini. Dan, termasuk didalamnya yakni permasalahan mu'amalah.

Salah satu yang diharamkan Islam secara normatif dalam bertransaksi adalah praktek riba. Ayat yang didukung hadist Nabi telah jelas mengharamkannya. Persoalannya sekarang adalah, apakah kemudian jika dalil yang menjadi dasar pengharamannya saat ini dapat menggugurkan hukum asalnya?

\section{Pengertian Riba}

Menurut bahasa "RIBA" berarti "ZIYADAH" (tambahan). Sedang menurut pengertian Syara', adalah: tambahan atau kelebihan tanpa imbalan jasa atau barang yang diharuskan bagi salah satu dari dua orang yang mengadakan $a k a d^{4}$.

Selanjutnya dalam analisis, disebutkan bahwa unsur-unsur riba itu ialah:

${ }^{2}$ HR. Akhmad dan Abu Daud.

${ }^{3}$ Abd al-Haq Humaisy dan Al-Husein syawat (2001). Figh Al 'Uqud Al Maliyyah. Amman (Jordan): Dar Al-Bayariq.

${ }^{4}$ Keputusan Tarjih Muhammadiyah (1989), Malang. 
a. Dilakukan antar perorangan yang menentukan syarat keuntungan secara sepihak.

b. Bersifat penghisapan yang menimbulkan kesengsaraan baik bagi perorangan maupun masyarakat.

Kemudian, adakah riba itu dihalalkan? Jawabannya adalah: tentang "hukumnya", riba itu "HARAM". Dalil yang menunjukkan hukum riba itu haram ialah ayat Al-Qur'an dan Sunnah Rasul'5. Larangan riba muncul dalam Al-Qur'an dan 4x penurunan wahyu yang berbeda-beda;

a. Ar-Ruum: 39, diturunkan di Mekah, menegaskan bahwa bungan akan menjauhkan keberkahan Allah dalam kekayaan, sedangkan sedekah akan meningkatkannya terlipat ganda.

b. An-Nisaa': 161, diturunkan pada masa permulaan periode Madinah, mengutuk dengan keras praktek riba, seirama dengan larangannya pada kitab-kitab terdahulu.

Pada tahap kedua ini, Al-Qur'an mensejajarkan orang yang mengambil riba dengan mereka yang mengambil kekayaan orang lain secara tidak benar dan mengancam kedua pihak dengan siksa Allah yang amat pedih.

a. Ali 'Imron: 130-132, diturunkan pada kira-kira tahun kedua atau ketiga Hijrah, menyerukan kaum muslimin untuk menjauhi riba jika mereka menghendaki kesejahteraan yang diinginkan (dalam pengertian Islam yang sebenarnya).

b. Al-Baqarah: 275-281, diturunkan menjelang selesainya misi Rasulullah SAW mengutuk keras mereka yang mengambil riba, menegaskan perbedaan yang jelas antara perniagaan dan riba, dan menuntut kaum muslimin agar menghapuskan seluruh utang-piutang yang mengandung riba, menyerukan mereka agar mengambil pokoknya saja, dan mengikhlaskan kepada peminjaman yang mengalami kesulitan. Rasulullah juga mengutuk, dengan mengsunakan kata-kata yang sangat terang, bukan saja mereka yang mengambil riba, tetapi juga mereka yang memberikan riba dan para penulis yang memberikan riba dan para penulis yang mencatat transaksi atau para saksinya.

Bahkan beliau menyamakan dosa orang yang mengambil riba dengan dosa orang yang melakukan zina 36 kali atau setara dengan orang yang mengzinai ibunya sendiri.

\section{"Padahal Allah telah menghalalkan jual beli dan mengharamkan riba."}

Dari ayat tersebut jelas dapat difahami bahwa hukum riba adalah haram”.

${ }^{5}$ Asymuni Abdurrahman, Tanya Jawab Agama II, pen. Suara Muhammadiyah, 1992.

${ }^{6} \mathrm{Al}-$ Baqarah (2) 275. 
M. Fajar Hidayanto: Praktek Riba danKesenjangan Sosial ...

Hadists yang diriwayatkan oleh Bukhari-Muslim yang artinya :

"Jauilah tujuh hal yang merusak; maka ada yang menanyakan hal itu: ya Rasulullah apa yang dimaksud dengan 7 perusak itu? Nabi menjawab: Memusyrikkan Allah, melakukan sibir, membunuh yang diharamkan Allah, makan riba, makan harta anak yatim, lari dari pertempuran dihari penyerbuan dan menuduh zina wanita mukmin yang baikbaik. $^{7}$

Dari ayat dan Hadist diatas, diketahui bahwa riba itu hukumnya haram.

Bahwa tentang "pelarangan riba", hal ini masuk dalam kategori mengambil atau memperoleh harta dengan cara tidak benar,..." wrongfull devouring of property".

Ayat-ayat yang melarang riba dengan lebih tegas dan jelas;

"Hai orang-orang yang beriman, janganlah kamu memakan riba dengan berlipat ganda dan bertaqwalah kamu kepada Allah supaya kamu mendapat keberuntungan. ${ }^{8}$

"Orang-orang yang makan (mengambil) riba tidak dapat berdiri melainkan seperti orang yang berdirinya kemasukan syaitan lantaran (tekanan) penyakit gila. Keadaan mereka yang demikian itu adalah kerena mereka berkata (berpendapat), sesungguhnya jual-beli itu sama dengan riba, padahal Allah telah menghalalkan jual-beli dan mengharamkan riba. Orang-orangyang telah sampai kepadanya larangan dari tuhannya, lalu terus berhenti (dari mengambil riba), maka baginya apa yang telah diambilnya dahulu (sebelum datang larangan); dan urusannya (terserah) kepada Allah. Orang yang mengulangi (mengambil riba), maka orang itu adalah penghuni-penghuni neraka; mereka kekal di dalamnya. Allah memusnahkan riba dan menyuburkan sedekah dan Allah tidak menyukai setiap orang dalam kekafiran, dan selalu berbuat dosa. Sesungguhnya orang-orangyang beriman, mengerjakan amalsholeh, mendirikan sholat, dan menunaikan zakat, mereka mendapat pahala disisi Tuhannya. Tidak ada kekhawatiran padanya dan tidak pula mereka bersedih hati. Hai orang-orang yang beriman, bertaqwalah kepada Allah dan tinggalkan sisa riba (yang belum dipungut) jika kamu orang-orang yang beriman. Jika kamu tidak mengerjakan (meninggalkan sisa riba), maka ketahuilah bahwa Allah dan Rasul-Nya akan memerangimu. Dan jika kamu bertaubat (dari pengampunan riba), maka bagimu pokok hartamu; kamu tidak menganiaya dan tidak pula dianiaya."

"Dan disebabkan mereka memakan riba, padahal sesungguhnya mereka telah melarang daripadanya, dan karena mereka memakan harta orang dengan jalan yang batil. Kami telah menyediakan untuk orang-orang

${ }^{7}$ HR. Bukhari dan Muslim, Abu Dawud dan An-Nasaiy dari Abu Hurairah. ${ }^{8}$ Ali Imran (3): 130.

${ }^{9}$ Al-Baqarah (2): 275-279. 
yang kafir di antara mereka itu siksa yang pedih. ${ }^{10}$

"Dan sesuatu riba (tambahan) yang kamu berikan agar dia bertambah pada harta manusia, maka riba itu tidak akan menambah pada sisi Allab: Dan jika apa yang kamu berikan berupa zakat yang kamu maksudkan untuk mencapai keridhoan Allah, maka (yang berbuat demikian) itulah orang-orang yang melipatgandakan (pahalanya). ${ }^{11}$

Untuk itu bahwa jual beli tidak sama dengan riba. Karenanya akan menjadi sangat penting untuk dapat membedakan antara riba dan perdagangan biasa. Bisa jadi bahwa riba yang di maksud dalam ayat-ayat tersebut adalah sebagaimana yang dipahami saat Al-Qur'an diturunkan. Salah satunya adalah "riba Al-Jahilliya", yaitu penambahan jumlah hutang bagi peminjaman yang tidak dapat membayar pada saat jatuh tempo. Sederhananya adalah doubling and redoubling yang sangat mirip dengan compound interest.

Rasulullah mendeskripsikan contoh-contoh pinjaman dan perdagangan yang dianggap riba.

"Dari UsamahbinZaid, bahwasanya Rasulullah bersabda: "Sesungguhnya riba itu bisa terjadi pada jual-beli secara hutang (kredit)". ${ }^{2}$

Dari Usamah bin Zaid, bahwasanya Rasulullah bersabda :

"Riba tidak mungkin terjadi pada jual beli secara tunai". ${ }^{13}$

Fada'lah bin Ubay berkata bahwa "Keuntungan yang diperoleh dari pemberian pinjaman merupakan salah satu aspek dari riba". [Sunan al Bayhaqi]. Hadist-hadist tersebut sering ditunjuk sebagai penjelasan "riba Nasi'ah".

Keterangan yang lain merujuk sebagai "riba al-fadl; pertambahan karena faktor pertukaran, bukan alasan penagguhan.

"Dari Abu Said al Khudri, Nabi Ssa bersabda: jangan melebih-lebihkan satu dengan lainnya; "Jangan menjual perak untuk perak kecuali keduanya setara; dan jangan melebih-lebihkan satu dengan lainnya; dan jangan menjual sesuatu yang tidak tampak". ${ }^{14}$

Pelarangan riba tidak lantas membuat hutang-piutang tidak diperbolehkan. Paling tidak Al-Qur'an justru memberikan tata cara melakukannya dengan adanya catatan. Sebagai dasarnya QS. (2) : 282-285.

Dan Al-Qur'an juga menganjurkan pemberi pinjaman atau kreditan untuk memberi keringanan jika debitur atau peminjaman mengalami kesulitan dalam pembayaran.

"Jika orang berhutang itu dalam kesukaran, maka berilah tangguh

\footnotetext{
${ }^{10}$ An Nisaa'(4): 161.

${ }^{11}$ Ar- Ruum (30): 39.

${ }^{12}$ HR. Bukhari Muslim dan Ahmad.

${ }^{13}$ HR. Muslim: Nasa'i.

${ }^{14}$ HR. Bukhari ; Muslim, Tirmidzi, Nasa'i, dan Ahmad.
} 
M. Fajar Hidayanto: Praktek Riba danKesenjangan Sosial ...

sampai dia berkelapangan. Dan menyedekahkan sebagian atau seluruh hutang itu lebih baik bagimu jika kamu mengetahui". ${ }^{15}$

Dalam hadist yang dibolehkannya perihal utang piutang adalah.

"Sebaik-baik manusia adalah yang sebaik-baik membayar hutang." ${ }^{16}$

\section{Menghindari Riba dan Segala Sarana Riba Seperti Transaksi-Transaksi Kotor}

Riba termasuk satu dari tujuh perbuatan yang membinasakan. Orangorang yang memakan riba hanya akan berdiri sebagaimana orang-orang yang kesurupan setan. Al-Qur'an telah memaklumkan perang antara para pemakan riba dengan Allah dan Rasul-Nya. Itu merupakan ancaman keras yang tidak ada duanya dibandingkan dengan maksiat lainnya.

Karena siapa saja yang mencermati segala problematika di dunia yang klasik maupun modern, pasti akan mendapatkan kenyataan bahwa semua problematika ekonomi tersebut ujungnya akan kembali kepada bentuk kemungkaran berat ini. Seorang pengusaha muslim akan lebih menjaga diri agar tidak terjerumus dalam hubungan riba, dan mereka adalah orang yang paling jauh dari aktivitas yang berhubungan dengan riba melalui berbagai bentuk transaksi haram, meskipun secara zhahir tampak halal. Pada hakikatnya dalam Islam tidak di bolehkan untuk membuat trik transaksi yang bertujuan untuk menghalalkan yang telah diharamkan oleh Allah dan Rasul-Nya. ${ }^{17}$

Allah Swt berfirman menyinggung haramnya riba mengancam para pelakunya dengan siksa yang pedih di dunia dan di akhirat. ${ }^{18}$

Allah memaklumkan perang terhadap para pemakai riba. Dan Allah menganjurkan memberi kelonggaran kepada orang-orang yang terlilit hutang dan memberi sedekah kepada mereka. Allah befirman dalam Surat Al - Baqarah : 278 - 281.

Berkaitan dengan laknat terhadap setiap orang yang terlibat dalam aktivitas riba pada sisi manapun, baik sebagai pemakan riba, atau orang yang memberikannya, sebagai sekretaris pelaku riba, atau saksi sekalipun, semuanya di sebutkan dalam hadist Jabir bin Abdillah a.s, ia menceritakan bahwa Rasulullah SAW melaknatkan pemakan riba, orang yang memberikannya, juru tulisannya, dan saksi dari kedua belah pihak. Rasulullah menegaskan bahwa semuanya sama saja. ${ }^{19}$

Di antara siksa akhirat yang dipersiapkan oleh Allah bagi para pemakan

\footnotetext{
${ }^{15}$ Al-Baqarah (2): 280.

${ }^{16} \mathrm{HR}$. Muslim.

${ }^{17}$ Abdullah Al Mushlih (2004). Fiqh Ekonomi Keuangan Islam. Jakarta: Darul

${ }^{18}$ Al-Baqarah (2): $275-276$.

${ }^{19}$ HR. Muslim.
} Haq. 
riba itu disebutkan dalam hadist Samurah bin Junbud diriwayatkan bahwa ia menceritakan bahwa Rasulullah SAW bersabda :

"Tadi malam aku melihat dua orang lelaki yang mendatangi. Mereka berdua mengeluarkan aku ke sebuah tanah suci. Mereka berangkat membawaku hingga sampai ke sebuah sungai darah. Di situ terdapat seorang lelaki yang sedang berdiri. Di tengah sungai juga terdapat lelaki pula yang di depannya ada sebuah batu. Orang pertama berusaha keluar dari sungai. Tapi begitu ia hendak keluar, lelaki kedua melempar mulutnya dengan batu hingga ia kembali hingga kedalam sungai tersebut. Demikianlah seterusnya setiap kali ia hendak keluar, mulutnya dilempar dengan batu hingga terpaksa kembali lagi. Aku bertanya: "Siapakah lelaki itu? "Lelaki yang mengajakku berkata: "Itulah orang yang suka memakan riba."

\section{Riba, Bunga, dan Keuntungan}

Larangan Al-Qur'an terhadap penghasilan al-Riba adalah jelas dan pasti. Sepanjang pengetahuan tidak seorang pun mempermasalahkannya. Tetapi pertentangan yang timbul adalah mengenai perbedaan antara riba dengan bunga. Salah satu mazhab pemikiran percaya bahwa apa yang dilarang Islam adalah riba bukan bunga. Sementara suatu mazhab pemikiran lain merasa bahwa sebenarnya tidak terdapat perbedaan antara riba dan bunga. Karena itu, pertanyaan pertama yang harus dijawab ialah apakah ada perbedaan antara riba dalam Al-Qur'an dan bunga dalam dunia kapitalis. Yang kedua, sekalipun keduanya sama artinya, mungkinkah kita mempunyai suatu masyarakat yang bebas bunga? Pertanyaan terakhir tetapi ini tidak berarti tak penting, meminta perhatian yang seksama tehadap perbedaan antara bunga dan laba.

a. Agar dapat memberikan jawaban mengenai apakah riba (al-riba) dan bunga itu sama, orang harus mengerti arti Riba dalam prespektif sejarahnya yang tepat. Arti bebas istilah ini adalah pertambahan atau pertumbuhan, namun arti ini tidaklah berguna bagi tujuan analisis kita, karena setiap pertambahan seperti halnya pertambahan yang berasal dari perdagangan dan industri tidaklah dilarang. Tetapi digunakannya kata sandang al di depan Riba dalam Al-Qur'an, menunjukkan kenyataan bahwa al-Riba mengacu pada perbuatan mengambil sejumlah uang yang berasal dari seorang berutang, secara berlebihan. Hal ini lazim terdapat di kalangan orang Arab dan yang mereka kenal pada masa diwahyukan Al-Qur'an. Jelaslah harus demikian, karena suatu larangan yang berkaitan dengan persoalan rakyat sehari-hari harus dinyatakan dalam bahasa biasa. Oleh karena itu pada umumnya, para ulama menerimanya. Sekarang kita akan memperhatikan macam riba apakah yang sebenarnya terdapat di

\footnotetext{
${ }^{20}$ HR. Bukhari.
} 
kalangan orang Arab ketika itu. Sejumlah ahli hukum ternama mencoba mendefinisikan al-Riba pada zaman Jahiliyah. Menurut Mujahid (meninggal pada tahun 104 Hijriah), Riba zaman Jahiliyah, yang dilarang Tuhan, adalah bila seseorang berutang kepada orang lain, dan berkata pada si pemberi utang, "Saya akan memberi kepada Anda sedemikian banyak, jika Anda memberikan kepada saya perpanjangan waktu. "Imam Malik (meninggal tahun 119 Hijriah) berkata: Pada zaman Jahiliyah, yang dinamakan Riba adalah bila pada suatu ketika seseorang memberikan pinjaman untuk suatu jangka waktu tertentu dan bila periode itu telah habis, si pemberi utang bertanya kepada yang berutang, apakah ia akan mengembalikan utangnya atau menaikkan jumlahnya. Jika ia membayarnya, akan diterima, kalau tidak maka jumlah utang itu akan dinaikkan dan ia akan diberi perpanjangan waktu. Ibnu Jarir Tabari (meninggal tahun 310 hijriyah), menanggapi ayat yang terdapat dalam Surat Al-Baqarah, mengatakan : "Seorang peminjam disebut Murb, karena dia menduakalikan jumlah utangnya. Menanggapi ayat tersebut Surat Al-Imran yang melarang dikenakannya bunga dua atau empat kali lipat, katanya, bersumber pada Mujahid, bahwa inilah Riba zaman Jahiliyah. Pendapat yang hampir sama dinyatakan oleh Imam Razi (meninggal pada tahun 606 Hijriyah). Menurut Imam Razi, (meninggal pada tahun 606 Hijriah) dan Baidavi (meninggal tahun 685 hijriah). Menurut Imam Razi, rakyat zaman Jahiliyah, biasa meminjamkan uang mereka dan memperoleh riba setiap bulannya tanpa mempengaruhi jumlah uang yang dipinjamkan. Bilamana waktu pelunasan tiba, dimintakan jumlah pokok yang dipinjamkan dan jika yang berutang tidak mampu mengembalikannya, si pemberi utang menaikkan jumlah pinjaman untuk keuntungannya sendiri dan memberikan perpanjangan waktu. Demikianlah cara orang Arab pada jaman Jahiliyah melakukan transaksi kegiatan pinjam-meminjam. Akhirnya, Baidawi berkata:"jika seseorang harus menerima pelunasan utang sesudah waktu yang ditentukan, maka ia akan terus memperbesar piutang itu, sampai seluruh kekayaan si peminjam habis terisap oleh pinjaman (asal) yang kecil jumlahnya." Dari semua pernyataan yang diberikan oleh para ahli hukum terpelajar dari berbagai zaman, dapatlah dikatakan secara pasti bahwa Riba yang terdapat pada masa pra-Islam ialah perpanjangan batas waktu dan penambahan jumlah peminjaman uang sehingga berjumlah begitu besar, sehingga pada akhir waktu pinjaman itu, si peminjam akan mengembalikan kepada orang yang meminjamkan sejumlah dua kali lipat atau lebih dari jumlah pokok yang dipinjamkannya. Demikianlah, dinilai dengan tolok ukur etika sosio-ekonomimanapun, tingkat suku bunga "riba" dinilai melampaui batas. Maka datanglah larangan Al Qur'an akan riba dalam surat Al Baqarah ayat 275 .

Di sini penulis ingin sedikit membahas mengenai bunga. Haberler dalam karyanya Prosperity and Depression telah menyatakan dengan tepat, bahwa "penjelasan dan penentuan mengenai suku bunga masih saja menimbulkan 
lebih banyak pertentangan di antara para ahli ekonomi, dibandingkan dengan cabang lain dari teori mengenai bunga. Selanjutnya akan terlihat bahwa teoriteori tentang bunga tidak dapat menjawab pertanyaan, mengapa bunga itu dibayarkan. Tetapi konsesus pendapat mengganggap bahwa bunga merupakan tambahan tetap bagi modal. Dikemukakan bahwa tambahan yang tetap ini merupakan biaya yang layak bagi digunakannya uang dalam suatu proses produksi. Sedangkan Riba mengacu pada bunga uang yang terlalu tinggi pada peminjaman tidak produktif. Hal ini berlaku pada masa pra-Islam, ketika orang belum mengenal pinjaman produktif dan pengaruhnya pada pertumbuhan ekonomi. Tetapi bagi penulis, jika terdapat perbedaan antara Riba dalam Al-Qur'an dengan bunga dalam masyarakat kapitalis, hal itu hanya merupakan perbedaan tingkat, bukan perbedaan jenis, karenabaik Riba maupun bunga merupakan ekses atas modal yang dipinjam. Memang benar, Riba dianggap tidak canggih dibandingkan dengan bunga. Tetapi menyebut Riba dengan nama bunga yang tidak mengubah sifatnya. Kenyataan mengenal hal itu ialah bahwa istilah ekses harus diambil dalam arti yang relatif, karena apa yang merupakan ekses layak hari ini, mungkin dianggap suku bunga luar biasa tingginya atau bersifat Riba pada hari esok. Banyak perkumpulan koperasi Indo-Pakistan yang mengenakan bunga 12 ampai 15 persen, dan pada waktu itu dianggap layak. Sedangkan hari ini bunga sebesar itu dianggap terlalu tinggi. Karena itu dianggap layak. Sedangkan hari ini bunga sebesar itu dianggap terlalu tinggi. Karena itu, larangan terhadap Riba berarti dilarangnya semua jenis ekses atas modal yang dipinjam, entah dia kita sebut bunga yang terlampau tinggi, bunga atau penghasil modal. Sesungguhnya, modal yang ditanam dalam perdagangan mungkin membawa kelebihan yang disebut laba yang bersifat tidak tetap dan juga mengandung arti kemungkinan rugi. Namun modal yang ditanam dalam bank menghasilkan bunga tetap dan tidak mengandung arti kerugian apa pun. Selanjutnya, tidaklah tepat untuk mengatakan bahwa pada masa pra Islam pinjaman tidak diberikan untuk tujuan produksi. Kita mempunyai catatan yang menunjukkan bahwa orang Yahudi Madinah meminjamkan uang tidak hanya untuk tujuan konsumsi, tetapi juga untuk perdagangan. Adanya Mudarabah pada waktu itu saja atau persekutuan diam-diam dikalangan orang Arab tidak menunjukkan kenyataan bahwa bunga yang produktif tidak sedang digemari di kalangan mereka. Pada kenyataan perbedaan antara pinjaman produktif dengan yang tidak produktif adalah perbedaan dalam tingkatan. Jika bunga pada pinjaman konsumsi itu berbahaya, maka bunga pada pinjaman produktif tentu berbahaya juga karena ia merupaka biaya produksi, dan karena itu mempengaruhi harga. Konsumenlah yang harus memikul beban harga yang lebih tinggi itu. Karena itu, dalam analisis terakhir dapat dikatakan bahwa Riba dalam Al-Qur'an dan bunga pada perbankan modern merupakan dua sisi dari mata uang yang sama. Sekarang pertanyaan pendahuluan yang harus dijawab adalah mengapa bunga dibayarkan? 


\section{b. Mengapa Bunga Dibayarkan}

Tidak terdapat jawaban yang jelas atas pertanyaan mengapa bunga dibayarkan. Kita dapati perbedaan pendapat yang luas di kalangan para ahli ekonomi mengenai teori bunga. Banyak pemikir besar yang memandang pembayaran bunga sebagai hal yang tidak adil. Dalam karyanya Politics, Aristoteles membandingkan uang dengan ayam betina mandul yang tidak bisa bertelur. Menurut dia, sekeping mata uang tidak bisa beranak kepingan uang yang lain. Dalam karyanya Laws, Plato mengutuk bunga. Pada tahap dininya kekaisaran Romawi, menentang dikenakannya bunga. Walaupun bunga muncul dengan timbulnya kelas kapitalis, pembatasan yang berat, diadakan oleh orang Romawi dengan memberlakukan undang-undang mengenai suku bunga. Pada abad pertengahan, Gereja Nasrani melarang praktek mengambil bunga yang terlalu tinggi, dan memungut bunga, berlawanan dengan prinsip kebiasaan umum. Banyak di antara penganut Merkantilisme yang menganjurkan suku bunga yang rendah tetapi tidak dijelaskan sama sekali mengapa bunga dibayar. Para ahli ekonomi klasik seperti Adam Smith, Ricardo, dan lain-lain, menganggap bunga sebagai ganti rugi yang dibayarkan si peminjam kepada yang meminjamkan, untuk laba yang akan dibuat si peminjam dengan menggunakan uang dari Pihak yang meminjamkan. Ricardo menyatakan, "Kalau memang banyak yang dapat dilakukan dengan menggunakannya, banyak pula yang dapat diberikan dengan menggunakannya. "Tetapi para ahli ekonomi klasik tidak menjelaskan bagaimana mengaitkan laba yang berubah-ubah dengan bunga yang tetap.

Selanjutnya, argumen klasik mengenai pengaruh suku bunga pada tabungan sangat dikecam oleh para ahli ekonomi seperti Keyne. Dia berpendapat bahwa tingkat pendapatan lebih menjamin persamaan antara tabungan dan investasi daripada suku bunga. Tabungan tidak begitu tergantung pada bunga sebagaimana pada tingkat investasi dan kesempatan kerja. Para pengusaha, bukannya para penabung yang mengganggu keseimbangan dan membawa dinamisme pertumbuhan perekonomian. Demikianlah dapat dijelaskan kenaikan luar biasa dalam menabung selama abad sekarang ini walaupun terdapat penurunan tajam dalam suku bunga.

Sekelompok penulis klasik lain telah berusaha mempertimbangkan pertanyaan di atas ini dari sudut pandangan penyediaan. Seniorlah yang pertama kali menjelaskan bahwa pandangan penyediaan modal atau tabungan memerlukan pengorbanan dan penahanan diri. Tetapi ide mengenai menahan diri itu telah dikritik secara luas dengan alasan bahwa hal ini mengesankan adanya ketidaksenangan yang tegas, sekalipun banyak orang kaya menabung tanpa kegelisahan sedikitpun. Seseorang penulis sosialis, Lasalle, mencemoohkan Senior dengan berkata bahwa laba modal adalah upah menahan diri. Karena kritikan ini maka Marshall mengganti istilah menahan diri dengan menunggu. Menurut dia, bila seorang menabung, dia bukan tidak menggunakan konsumsi 
untuk selamanya, tetapi hanya menunda konsumsi sekarang untuk waktu yang akan datang. Suatu rangsangan justru diperlukan untuk mendorong penundaan semacam itu atau menunggu, dan rangsangan untuk itu adalah bunga.

Tetapi sesungguhnya semua penundaan konsumsi sekarang atau tindakan menunggu atau tidak memerlukan adanya rangsangan berupa bunga. Kedua, adalah tidak mungkin untuk mengembangkan kriteria seragam untuk menilai harga menunggu. Lagi pula, penjelasan ini mengabaikan segi permintaan, dan karenanya bersifat berat sebelah dan tidak lengkap. Bahkan teori produktivitas sebagai suatu sifat yang terkandung dalam modal, seperti juga tanah menghasilkan panen. Mereka berpendapat bahwa adanya bunga karena modal menyebabkan produksi yang lebih besar daripada bila tanpa modal. Tidak seorangpun dapat menentang bahwa modal itu produktif. Tetapi hal itu tidak menjelaskan mengapa suku bunga khusus dibayarkan. Jika bunga dibayar karena produktivitas modal, maka ia harus berubah, karena produktivitas itu sendiri cenderung berbeda dari industri satu ke industri lainnya, di negara yang sama pada suatu masa tertentu. Selanjutnya, jika modal membantu buruh untuk menghasilkan lebih banyak, berapa banyakkah produksi tambahan yang disebabkan oleh modal dan berapa banyak oleh tenaga kerja, karena modal tanpa tenaga kerja tidak menghasilkan suatu apa pun. Kemudian, pada umumnya pinjaman konsumsi tidak dianggap produktif, namum bunganya harus dibayar. Tidak jelas mengapa bunga tertentu harus dibayar, untuk pinjaman konsumsi yang mungkin digunakan untuk berbagai macam konsumsi. Seorang yang kaya mungkin menggunakan pinjaman itu untuk membeli sebuah mobil sedangkan seorang yang miskin mungkin menggunakannya untuk keperluan hidupnya. Sesungguhnya, semua teori produktivitas mengenai bunga, termasuk versi yang paling diterima, yaitu teori produktivitas marjinal mengenai bunga, yang tidak mempunyai ukuran. Tampaknya teori ini telah mengabaikan kenyataan bahwa sistem perekonomian itu dinamis. Suatu situasi keseimbangan baru selalu diganggu dengan adanya perubahan selera, jumlah penduduk, pola-pola tabungan serta investasi, dan dengan perubahan dalam nilai dan standar kehidupan.

Dalam kegiatan perekonomian, variabel-variabel ini mempunyai kecenderungan beroperasi dengan cara kumulatif dan melingkar, beraksi dan bereaksi satu sama lain dalam pola yang rumit. Mengabaikan mobilitas variabel ini sama dengan tidak mempedulikan kenyataan pokok mengenai perubahan dalam sistem perekonomian.

Kemudian, madzhab para ahli ekonomi Austria seperti Bohm-Bawerk memasukkan ide mengenai preferensi waktu dalam menjelaskan mengapa bunga dibayarkan. Menurut dia, bunga timbul, karena orang lebih menyukai barang di masa yang akan datang, dan karena kepuasan di masa itu, kalau dinilai dengan pendirian waktu sekarang, mengalami diskonto, maka bunga adalah diskonto harga. Bohm-Bawerk memberikan 3 alasan tentang mengapa orang lebih menyukai kepuasan sekarang dibandingkan dengan kepuasan dimasa yang akan 
datang, yaitu (a) pandangan yang rendah terhadap perspektif masa depan, (b) kelangkaan relatif barang sekarang dibandingkan dengan barang di masa yang akan datang, (c) keunggulan teknik atas barang di masa yang akan datang.

Seorang ahli ekonomi Amerika Irving Fisher menerima dua dalil pertama Bohm-Bawerk, tetapi menyangkal keabsahan dalil yang ketiga. Menurut dia, preferensi waktu adalah kenyataan pokok dalam teori bunga. Sikap individu lebih menyukai pendapatan sekarang daripada pendapatan di masa yang akan datang. Seperti yang telah dinyatakan oleh Fisher, keunggulan teknis barang sekarang ini merupakan khayalan, dan sebenarnya adalah suatu bentuk tersendiri dari teori produktivitas. Dengan demikian pernyataan itu dilemahkan oleh kesesatan penalaran yang disebut petitio principii (sesat penalaran karena mengandaikan sesuatu yang justru masih harus dipertimbangkan). Jika sumber-sumber daya semakin banyak dialihkan dari penggunaan sekarang ke masa yang akan datang, dan relatif terjadi kekurangan penyediaan untuk waktu sekarang. Barang untuk sekarang akan menjadi langka dan harganya akan lebih tinggi dari harga barang di masa yang akan datang. Lord Keynes mengecam teori kuno ini dengan alasan bahwa imbalan tidak perlu dibayarkan kepada siapapun karena menabung. Orang menabung, demikian pendapatnya, bilamana penghasilan dan tingkat hidupnya memungkinkannya berbuat demikian atau mereka menabung untuk persediaan di masa suram, dengan demikian tanpa mempedulikan imbalan yang diharapkan akan diterimanya, dengan cara menabung itu. Dengan perkataan lain, menabung merupakan tindakan sukarela dengan demikian tidak memerlukan imbalan atau rangsangan apa pun. Ini menjelaskan mengapa teori Bohm-Bawerk dan teori preferensi waktu Fisher tidak dapat diterapkan dalam hal tabungan perusahaan yang merupakan bagian terbesar tabungan di negara-negara maju terlepas dari tinggi rendahnya suku bunga.

Teori bunga neo-klasik yang pada pokoknya didasarkan atas teori bunga Bohm-Bawerk tidak lepas/luput dari kecaman Keynes. Teori ini menganggap suku bunga sebagai faktor yang membawa permintaan akan investasi dan kesediaan menabung ke dalam keseimbangan satu dengan yang lainnya. Sama seperti harga suatu komoditi perlu ditetapkan pada batas permintaan adalah sama dengan penyediaan, demikian pula suku bunga perlu ditetapkan pada batas jumlah investasi suku bunga itu sama dengan penyediaan, demikian pula suku bunga perlu pada batas jumlah investasi suku bunga itu sama dengan jumlah tabungan pada suku itu. Maka menurut teori neo klasik suku bunga, ditentukan oleh penyediaan dan permintaan akan dana yang dapat dipinjam. Semua teori moneter tentang bunga, termasuk teori dana yang dipinjam, ternyata telah mencampur adukan masalah penukaran dan masalah distribusi. Sementara teori harga mengacu pada masalah penukaran, teori bunga mengacu pada masalah distribusi.

Sumbangan terakhir tetapi ini bukan berarti tidak berguna terhadap teori mengenai bunga adalah diberikan oleh Lord Keynes. Sekalipun pada umumnya 
terdapat persetujuan bahwa pengertian preferensi likuiditas memperkenalkan variabel baru yang disambut dengan baik oleh teori bunga klasik, namun terdapat keengganan umum untuk meminta pernyataan bahwa teori baru itu menggantikan teori bunga tradisional. Walaupun seluruh teori Keynes mengabaikan pengaruh ganda gagasan penghematan dan produktivitas, namun teorinya itu sedikit banyak analog dengan teori bunga Bohm-Bawerk. Apa yang dinamakan Bohm-Bawerk pandangan rendah prespektif masa depan dan disebut Fisher preferensi waktu, disebut Keynes kecenderungan untuk mengkonsumsi. Sebenarnya kedua-duanya berdasarkan pada prototipe yang subjektif, preferensi untuk barang sekarang dari pada barang di masa yang akan datang. Suatu teori menganggap bunga sebagai premi pada barang sekarang, yang lainnya menyebutkan sebagai imbalan karena melepaskan likuiditas. Pada hakikatnya, kedua-duanya sama.

Dari penyelidikan singkat diatas mengenai semua teori bunga, ternyata bahwa para ahli ekonomi tidak dapat menemukan jawaban yang jelas dan pasti terhadap pertanyaan mengapa bunga dibayarkan. Selain itu, beberapa diantaranya hanya menjelaskan bagaimana ia ditentukan tanpa memperhatikan kenyataan bahwa penetapan suku bunga terlebih dahulu menghalangi mobilitas produksi dan pertumbuhan yang terkandung dalamnya. ${ }^{21}$

\section{Riba dapat Memperlebar Kesenjangan Sosial}

Majelis Ulama Indonesia (MUI) pada bulan Desember 2003 sudah mengeluarkan fatwa mengenai riba. Isinya yang paling penting yaitu bunga bank adalah haram, karena bunga model ini telah memenuhi syarat-syarat riba yang diharamkan oleh Al Qur'an. Poin yang kedua, di daerah yang belum terdapat lembaga keuangan syari'ah, maka lembaga keuangan konvensional tetap dibolehkan atas dasar darurat. Poin yang ketiga, orang yang bekerja di lembaga keuangan konvensional, tetap dibolehkan sepanjang ia belum mendapatkan pekerjaan yang baru yang sesuai dengan syari'ah."Jadi masih ada kelonggaran, namun tidak bisa selamanya dianggap darurat," menurut pakar hadist Prof. Dr. KH Ali Musthafa Ya'kub.

Islam adalah rahmat bagi seluruh alam. Karenanya dalam bermuamalah, Islam menghendaki terciptanya sebuah sistem ekonomi dimana segala bentuk eksploatasi (penganiayaan) ditiadakan.Bahwa"sistem riba sungguh tidak sejalan dengan semangat ini.

Prof. Dr. KH. Didin Hafidhuddin mengungkapkan; ada sebuah penelitian di NEF (The New Economic Foundation) yang menyatakan karena sistem ekonomi sekarang ini adalah sistem ribawi, bergerak kepada kesenjangan yang semakin melebar. Dari pengamatan yang dilakukan selam 20 tahun, ternyata

${ }^{21}$ Muhammad Abdul Mannan (1993). Ekonomi Islam: Teori dan Praktek. Yogyakarta: Dana Bakti Wakaf. 
dari setiap 100 Euro yang dinikmati dhuafa Cuma 0,6 persen.Berarti orang kaya menikmati 99,4 persen. Untuk itulah, apabila sistem ekonomi ribawi masih dijalankan, tidak akan pernah bisa mengangkat ekonomi masyarakat.

Landasan bank syariah dengan bank konvensional sangat berbeda. Kalau bank konvensional komersial, sedangkan bank syariah sektoral. Kalau semakin berkembang bank syariah, maka sektor riil akan semakin berjalan. Kalau di bank syariah bukan semata boleh dan tidak boleh, tetapi juga akhlaknya serta etikanya.

Sekjen PP Muhammadiyah Good-Will Zubair mengatakan masalah bank sampai hari ini, para ulama di dunia masih dua pendapat dalam memahami tentang ayat riba. Ada yang menyebut bunga bank "haram", tapi ada jga yang menyebut "halal". Ulama ang menganggap bunga bank haram berpendapat; karena bunga bank melebihi dari apa yang telah ditentukan (dari pinjaman). Sedangkan ulama yang berpandangan bunga bank halal mengatakan; karena menganggap bank itu untuk kemaslahatan orang ramai, bukan untuk kepentingan pribadi. Karena itu mereka menganggap halal, ujung-ujungnya dianggap bunga bank itu syubhat.

Persoalannya , dalam agama Islam kalau dijatuhkan ke syubhat hukumnya jelas yakni kita disuruh untuk menjauhkan dari yang syubhat.Sampai hari ini ulam di dunia bukan saja di Indonesia, tapi di seluruh dunia masih ada dua pendapat soal bunga bank. Lalu muncullah bank syariah yang sifatnya bagi hasil.

Persoalan yang lain, apakah masalah riba sudah pada tarap mencekik umat seperti yang terjadi pada zaman Rasulullah SAW ? jawabannya adalah; sekecil apapun dan sebesar apapun,di manapun tempat perbutannya jelas mencekik umat. Untuk itulah Allah tegas-tegas katakan menghalalkan jual beli dan mengharamkan riba. Dalam QS. Ali Imran ada kata-kata "mudhaafah". Di manapun tempatnya, berapapun jumlahnya yang jelas riba itu mencekik. Justru itulah agama kita melarang perbuatan riba.

Sementara mantan Ketua Komisaris Fatwa MUI, KH Ma'ruf Amin mengatakan mengapa komisi fatwa MUI menfatwakan bunga bank itu haram karena banyak orang yang bertanya soal bunga bank sehubungan dengan berdirinya bank syariah. selanjutnya juga dijelaskan dalam berbagai forum internasional, yang dilakukan oleh para ulama menegaskan bahwa bunga bank itu haram. Pertama, Majmaul Bhu'us, di mesir tahun 1965 menetapkan bahwa bunga bank itu haram. Keua, Majmaul Fikih di Jeddah tahun 1985 menetapkan bunga bank itu haram. Ketiga, Majmaul Fikih Rabithal Alam Islami tahun 1986 di Mekkah menetapkan bahwa bunga bank itu haram. Jadi, menurut Yusuf Qardhawi ketetapan bunga bank haram itu merupakan "Ijmaul Majami' (kesepakatan berbagai forum). Jadi intinya MUI hanya menyuarakan kesepakatan tersebut.

Ditegaskan juga bahwa bank syari'ah itu tidak ada instrumen bunga, yang ada adalah bagi hasil, jual beli dan pelayanan. Wakala, kafala, dan ujrah fi itu merupakan bank syariah. Memang masih disayangkan,sampai saat ini 
belum maksimalnya umat Islam memanfaatkan bank syariah walaupun bank syariah sudah bermunculan di mana-mana. Umat Islam Indonesia itu aneh dan lucu, akidahnya Islamiyah, ibadahnya Islamiyah tapi muamalahnya masih ribawiyah, karena itulah perlu terus disadarkan supaya mereka menggunakan sistem syariah. ${ }^{22}$

\section{Praktek Riba dalam Bertransaksi}

Dalam hal mu'amalah, Islam telah menawarkan panduan yang jelas dalam setiap transaksi. Semua ketentuan yang ada itu tidak lain bertujuan untuk menghasilkan transaksi yang halal dan tayyib. Islam juga telah menggariskan jenis-jenis transaksi yang dilarang seperti membuat dan menjual barang-barang yang najis, seperti bangkai, babi, anjing, tahi, arak, kencing, dll. Barang-barang tersebut adalah haram li zatihi, karena Rasulullah SAW bersabda : "Sesungguhnya Allah SWT jika mengharamkan seuatu barang, maka harganyapun haram juga". 23 Membuat barang-barang yang tidak bermanfaat dalam Islam (membawa kepada mafsadat dan maksiat) atau yang mendatangkan kelalaian hingga menyebabkan seseorang individu itu lupa untuk beribadah kepada Allah juga tidak dibenarkan. Transaksi yang mengandung unsur riba, gharar, perjudian Bay' ma'dum, melakukan penipuan dalam transaksi, membeli di atas belian orang lain, melakukan penimbulan (ihtikar), dan lain-lain.

Alasan dan landasan normatif yang digunakan ahli fiqih dalam hal ini merupakan dasar yang telah ada sejak awal Islam muncul ke permukaan (yaitu pada zaman Rasulul hidup), sehingga setiap dalil memiliki konteks dengan masyarakat yang hidup disekitar Nabi pada saat itu. Inilah kemudian yang sering menjadi bahan perdebatan para ahli yang hidup saat ini. Pendeknya, sesuatu yang menjadi ideal (sesuai dengan konsep) pada saat itu tidak sepenuhnya dapat diterapkan pada realita (yang sering bergantung pada kebutuhan) masyarakat yang hidup saat ini. Dan termasuk di dalamnya adalah permasalahan mu'amalah.

Salah satu yang diharamkan Islam secara normatif dalam bertransaksi adalah praktek riba. Ayat yang didukung hadist Nabi telah jelas mengharamkannya. Namun, apakah kemudian jika dalil yang menjadi dasar pengharamannya tidak sesuai dengan konteks masyarakat saat ini dapat menggugurkan hukum asalnya itu. Lebih "rame" lagi jika perkara itu ditilik dengan kebutuhan dan kepentingan satu komunitas masyarakat. Dalam makalah ini, saya bermaksud membahas mengenai konsep riba dari aspek normatif-kontekstual dengan masyarakat saat ini.

Secara ringkasnya, bahwa unsur-unsur riba adalah sebagai berikut:

a. Adanya tambahan dari jumlah pokok pinjaman

\footnotetext{
${ }^{22}$ Republika, Jum'at Juni- 2007.

${ }^{23} \mathrm{HR}$. Ahamad dan Abu Daud.
} 
M. Fajar Hidayanto: Praktek Riba danKesenjangan Sosial ...

b. Penentuan tambahan itu berkaitan dengan unsur pertimbangan jangka waktu

c. Tawar menawar atau persetujuan terhadap syarat tambahan ditentukan terlebih dahulu yaitu ketika pinjaman kontrak dilakukan

Dalam mu'amalah (transaksi), riba biasanya mempunyai tiga bentuk yaitu:

a. Bayaran balik yang melebihi jumlah uang pokok (harta asal) yang dipersyaratkan

b. Terlebih dahulu ketika kontrak dilakukan

c. Kontrak ke atas pertukaran barang tertentu yang tidak diketahui dengan pasti persamaannya pada timbangan atau takaran yang diakui oleh syara'

d. Penangguhan penyerahan salah satu barang yang ditukarkan atau yang diperdagangkan (khususnya untuk pertukaran mata uang dan barang ribawi).[Abd. Mumin Ab. Gani (1999). Sistem Kewenangan Islam dan Pelaksanaannya di Malaysia. Kuala Lumpur: Jabatan Kemajuan Islam Malaysia.]

Umat Islam dilarang mengambil riba apapun jenisnya, karena Al Qur'an dan hadits Rasulullah SAW yang merupakan sumber utama hukum Islam, secara jelas melarangnya. Ulama pun telah bersepakat (ijma') bahwa riba adalah haram.

a. Larangan riba dalam Al Qur'an

Turunnya ayat mengenai riba dalam Al Qur'an secara bertahap yakni ada empat tahap, yang terdiri dari 8 ayat dalam 4 syrat, yaitu Al Baqarah sebanyak 5 ayat, Ali Imran sebanyak 1 ayat, dan Ar Rum ada 1 ayat. Satu ayat diturunkan di Mekah dan selebihnya di Madinah. Gaya pengharaman riba dalam Al Qur'an sangat mirip dengan bentuk pengharaman khamr dalam Al Qur'an. ${ }^{24}$ Yaitu tidak mengharamkan sekaligus tetapi berangsur-angsur. Bahkan dalam hadist pun juga terdapat kesamaan dalam hal dosa dari dua perbuatan dosa tersebut yaitu mendapat laknat dari Allah SWT. ${ }^{25}$ Apabila ditinjau dari kontek sejarah, hal itu wajar terjadi. Karena masyarakat pada saat itu terbiasa praktek seperti ini.Tentang riba ini ada yang mengatakan sama saja dengan jual beli yang diperbolehkan Islam.

Bahwa tidak semua perkara yang diharamkan oleh Allah SWT. Tidak ada manfaat nya sama sekali atau hanya mendatangkan madharat saja. Hal ini terbukti dari ungkapan Allah dalam Al Qur'an sarah Al Baqarah:219 tentang keharaman khamr, yang mana khamr itu mengandung manfaat tetapi madharatnya lebih besar dan berbahaya daripada manfaat yang mungkin diperoleh. Demikian juga riba, mungkin ia mengandung manfaat tertentu

${ }^{24}$ Wahbah Zuhaili (1997). Al Figh Al Islami Wa Adillatuh, juz.3,cet.4. Beirut: Dar Al Fikr.

${ }^{25}$ Ibnu Hajar Al Asqalan(1994). Bulugul Al Maram Min Adillati Al Abkam. Bandung: Gema Risalah Press. 
pada sekelompok orang tertentu, tetapi ternyata bahaya riba lebih besar daripada manfaat yang ditimbulkannya.

b. Larangan riba dalam Al Hadist

Fungsi utama hadist adalah untuk menjelaskan lebih lanjut ketentuanketentuan hukum yang telah digariskan oleh Al Qur'an dan juga terkadang menjelaskan hukum tersendiri.Dalam hal pelarangan riba dalam hadist yang bersifat umum dan Ada yang merupakan penjelasan lebih terperinci dari ketentuan Al-Qur'an. Dalam amanat terakhirnya ketika khutbah haji wada', Rasulullah menegaskan sikap Islam yang melarang keras terhadap riba, Rasul bersabda: "Ingatlah bahwa semua riba yang diamalkan pada zaman jahiliyyah dihapuskan dari amalan kamu. Kamu berhak mengambil modal (uang pokok) yang kamu berikan, niscaya kamu tidak menzalimi dan tidak dilazimi.."26

Selain itu, masih banyak hadist Rasulullah SAW yang menjelaskan tentang larangan riba, diantaranya (artinya) :

1. Jabir berkata bahwa Rasulullah SAW mengutuk orang yang menerima riba, orang yang membayarnya, orang yang mencatatnya, dan 2 orang saksinya, kemudian beliau bersabda, "Mereka itu semuanya sama. ${ }^{\text {27 }}$

2. Dari Abu Hurairah r.a., Nabi bersabda, "Pada malam miraj saya telah bertemu dengan orang yang perutnya besar seperti rumah, didalamnya dipenuhi oleh ular-ular yang kelihatan dari luar, lalu saya bertanya kepada Jibril, siapakah mereka? Jibril menjawab, mereka adalah orang-orang yang memakan riba". ${ }^{28}$

c. Ijma' ulama

Para ulama salaf maupun khalaf telah bersepakat (ijma') bahwa riba adalah haram, baik sedikit atau banyak. Dinyatakan bahwa riba merupakan salah satu dari tujuh dosa besar yang harus dihindari. Adapun pengharaman itu jikasalah satu masyarakat berada dalam kondisi yang normal, tidak dalam keadaan yang terpaksa (dharurah). Nah, sebagai episode selanjutnya, para ulama kembali berbeda pendapat dalam menetapkan kadar kondisi yang darurat itu, sebagaimana yang terjadi di Indonesia.

Dengan demikian, jelaslah bahwa secara tegas Al-Qur'an dan al-Sunnah serta ijma ulama mengharamkan riba dalam bentuk apapun juga. Hanyasaja, dalam realitas kehidupan, wujud riba seringkali mengkaburkan dan menyamarkan orang, disamping pemahaman ulama juga terkadang berbeda-beda dalam memahami maksud nas dalam memberikan hukum terhadap realitas yang terjadi di lapangan kehidupan. Khususnya dalam hal apakah bunga dalam dunia perbankan, asuransi dan lain-lain lembaga keuangan konvesional termasuk riba yang diharamkan. Dalam kaitannya dengan hal ini, berikut

\footnotetext{
${ }^{26}$ HR. Muslim.

${ }^{27}$ Ibid.

${ }^{28}$ HR. Ibnu Majah.
} 
ini dijelaskan fatwa-fatwa ulama tentangnya:

1. Fatwa MUI

Pada tanggal 16 Desember 2003, Ulama Komisi Fatwa Majelis Ulama Indonesia (MUI) se-Indonesia menetapkan fatwa bahwa bank, asuransi, pasar modal, pengadaian, koperasi, dan lembaga keuangan lainnya maupun individu yang melakukan praktek bunga adalah haram. Ini artinya umat Islam tidak dibolehkan melakukan transaksi dengan lembaga keuangan konvesional tersebut. Pada awalnya Fatwa larangan untuk bermuamalah dengan lembaga keuangan konvesional yang berasaskan riba ini tidak berlaku mutlak untuk seluruh wilayah Indonesia. Untuk wilayah yang belum ada kantor/jaringan lembaga keuangan syri'ah dibolehkan melakukan kegiatan transaksi berdasarkan prinsip darurat atau hajat (keperluan). Akan tetapi dengan adanya kartu SharE yang diterbitkan oleh Bank Muamalat Indonesia (BMI) yang dapat dimanfaatkan dan diakses dimana jua pun di wilayah Indonesia, maka mulai saat diluncurkannya kartu SharE ini, bunga bank adalah haram secara mutlak. ${ }^{29}$

2. Sidang Organisasi Konferensi Islam (OKI)

Semua peserta Sidang OKI kedua yang berlangsung di Karachi, Pakistan, Desember 1970, telah menyepakati dua hal utama yaitu:

a. Praktek bank dengan sistem bunga adalah tidak sesuai dengan syariah Islam.

b. Perlu segera didirikan bank-bank alternatif yang menjalankan operasinya sesuai dengan prinsip-prinsip syariah. Hasil kesepakatan inilah yang melatarbelakangi didirikannya Bank Pembangunan Islam atau Islamic Development Bank (IDB).

3. Muktamar Majma'al-Buhuth al-Islamiyyah

Ulama-ulama besar dunia yang terhimpun dalam Majma' Al Buhuth Al Islamiyyah telah memutuskan hukum yang tegas terhadap bunga bank. Dalam konfrensi keduanya yang diselenggarakan di Kairo, pada bulan Mei 1965 ditetapkan bahwa praktek pembungaan uang seperti yang dilakukan bank-bank konvensional adalah riba yang diharamkan. Selain itu masih terdapat hasil muktamar para ulama mengenai perkara ini yang berbeda satu sama lain.

\section{Macam-Macam Riba}

Berdasarkan jenis kontrak yang terlibat, riba dibagi menjadi dua;[Muhammad Ibn Ahmad Ibn Muhammad Ibn Rusy (1988). Bidayah Al Mujtahid Wa Nihayah Al Muqtasid. Beirut: Dar Al Qalam.] yaitu:

${ }^{29}$ Republika, 10 Mei- 2005. 
1. Riba Duyun (Riba Hutang Piutang)

Yaitu riba pinjam meminjam yang timbul dari pinjaman uang. Riba jenis ini ada2 yaitu:

\section{a. Riba Jahiliyyah}

Yakni riba yang berupa bunga terhadap hutang yang dipersyaratkan ketika akad berhutang terjadi atau apabila penghutang gagal membayar pinjaman pada waktu yang ditetapkan maka pemiutang akan mensyaratkan supaya membayar suatu jumlah tambahan bagi peminjam pokok yang telah diberi. Semua ulam sepakat tentang kekharamannya.

b. Riba Qardh (Riba Pinjaman)

Yakni riba pada bunga dari pinjaman uang yang telah ditetapkan pada permulaan kontrak hutang oleh pemiutang (kreditur). Dalam hal ini, riba juga terjadi jika pihak yang berhutang berjanji untuk membayar dengan jumlah yang lebih ketika dia membayar hutang tersebut semasa akad hutang dibuat. Hukumnya adalah haram dan tidak sah.

Bahwa faedah (bunga) yang diharamkan adalah karena pinjam-memimjam. Sedangkan faedah yang terjadi karena transaksi jual beli secara bertangguh (albay'al-mu'ajjal) adalah dibolehkan menurut Jumhur Ulama. Konsekuensinya menjual barang dengan harga yang lebih tinggi secara kredit (bay' al-mu'ajjal) dengan harga yang lebih tinggi daripada harga cash adalah dibolehkan berdasarkan pendapat jumhur ulama. Hal ini seperti dalam bay'al-murabahah, bay' bi thaman ajil'.

2. Riba Buyu' (riba jual beli)

Jenis riba ini ada 2 macam yaitu:a. Riba Fadhl yaitu; pertukaran barang ribawi yang sama rupa dan bentuknya yang disertai tambahan atau seseorang itu menjual suatu barang ribawi dengan barang ribawi yang sejenis. Riba ini terjadi pada jual beli naqd(emas dan perak) b. Riba Nasiah yaitu riba yang terjadi dalam jual beli secara kredit. Riba ini ada 2 bentuk; 1 . Jual beli barang ribawi yang sejenis dan sama banyak tetapi dilakukan secara kredit. 2. Pertukaran barang ribawi dengan barang ribawi lainnya yang tidak sejenis secara kredit. Tentang larangan riba ini tidak peduli banyak ataupun sedikit jumlah riba yang diambil,semua diharamkan.

Riba merupakan kejahatan yang meruntuhkan hakikat dan tujuan Islam dan iman.Riba juga menyebabkan hancurnya ukhuwah. Juga merupakan pemerasan manusia terhadap manusia yang lain.Dampaknya terhadap ekonomi antara lain ;adanya hutang, dengan rendahnya tingkat penerimaan peminjam dan tingginya bunga, akan menjadikan peminjam ketergantungan yang berakibat terjadi kemiskinan.

Secara moral spiritual, riba juga menyebabkan berkembangnya sifat tama', cinta harta yang berlebihan, bakhil dan sombong. Hal ini akan berdampak pada sifat egois, mementingkan diri sendiri. 
Dalam kehidupan sekarang ini, terjadi perkembangan aktifitas ekonomi seperti; bank, asuransi, transaksi obligasi, transaksi valas. Umat Islam dihadapkan pada kondisi yang sangat sulit, hampir sebagian besar masalah ekonomi mengandung unsur riba. Jika kita tidak hati-hati bisa terjebak pada riba.

Perlu diketahui, dalam praktek bank Islam pun bisa terjadi riba. Misalnya adanya bunga yang diakali (bunga yang dihilah) dengan cara mengenakan biaya administrasi yang tinggi, dalam masalah pinjaman (al-qard). Seolah-olah kita memang tidak dikenakan bunga tetapi dikenakan biaya administrasi yang sangat tinggi.

Dimasyarakat riba dihidupkan, terutama pada rentenir atau lintah darat dengan cara memberikan pinjaman pribadi kepada fihak lainnya dengan bunga yang tinggi. Dan biasanya para peminjam adalah orang-orang kecil seperti; petani, pedagang kecil, nelayan.

\section{Riba dan Globalisasi Ekonomi}

Didalam surat Al Baqarah ayat 261 sampai dengan 274 kepada umat Islam diberi tuntunan bagaimana seharusnya kita menggunakan harta. Kita sebagai muslim dituntut untuk menggunakan harta untuk:

1. Memperkuat ketaqwaan kepada Allah SWT

2. Memperkuat hubungan silaturahmi sesama manusia

3. Berbuat amal yang benar

Secara garis besar isi dari masing-masing ayat tersebut ialah: harta yang dinafkahkan dijalan Allah akan bertambah berlipat ganda ibarat sebutir benih yang menumbuhkan tujuh butir ada seratus biji (ayat 261), kemudian mereka mengiringi apa yang dinafkahkannya itu dengan menyebut-nyebut pemberiannya dan tidak menyakiti fihak yang menerima (ayat 262). Perkataan yang baik dan tindakan memberi ma af lebih baik daripada sedekah yang diiringi dengan sesuatu yang menyakitkan perasaan si penerima (263). Janganlah kamu menghilangkan pahala sedekahmu dengan menyebut-nyebutnya an menyakiti perasaan si penerima (264). Perumpamaan orang yang menafkahkan harta karena mencari ridho Allah adalah ibarat sebuah kebun yang terletak di dataran tinggi yang subur memperoleh hujan yang cukup sehingga menghasilkan panen dua kali lipat (265). Apakah kamu ingin mempunyai kebun dengan bermacam-macam buah-buahan kemudian pada masa tuamu kebun itu ditiup angin keras yang mengandung api lalu terbakarlah kebun itu, sedangkan kamu masih mempunyai keturunan yang masih kecil-kecil, agar kamu berfikir (266). Jika kamu menampakkan sedekahmu (agar dicontoh orang lain) itu adalah baik, jika kamu menyembunyikan pemberian sedekah itu adalah baik (271). Orang-orang yang menafkahkan hartanya di malam hari dan di siang hari baik sembunyi-sembunyi, maupun terang-terangan akan mendapat pahala disisi Tuhan(274).

Dengan harta yang kita miliki dan makin bertambah, hendaklah dipakai 
untuk mendekatkan diri pada Allah swt. Dalam menghadapi masa globalisasi dalam segala bidang, termasuk globalisasi ekonomi nampaknya tidak ada batas lagi antar negara, dunia makin transparan, kejadian dibelahan dunia lain dalam tempo sekian detik kita dapat mengetahuinya via satelit dan jaringan informasi yang serba canggih. Kekuatan ekonomi makin menyatu, mereka bergabung dalam bentu merger, join venture dan sebagainya.

Kalau aktivitas mereka tidak dibimbing oleh suatu etik tertentu, maka mereka mulai menghilangkan batas-batas yang baik dan yang buruk, yang boleh dan terlarang, mereka mulai mengaburkan yang halal dan yang haram. Kemajuan usaha yang mereka peroleh tidak terlepas dari hubungan utang-piutang yang terjadi di antara mereka baik pengusaha industri, perdagangan, pertanian dengan perusahaan perbankan atau pinjam-meminjam antar individu dan perusahaan lain. ${ }^{30}$

\section{IX.Optimalkan Ekonomi Syariah}

Terkait dengan uraian riba dan globalisasi ekonomi, kita perlu belajar dari krisis keuangan global. Bahwa rekayasa instrumen keuangan yang berbentuk subprime mortgage menjadi salah satu sebab timbulnya krisis ekonomi di Amerika Serikat. Larisnya subprime mortgage atau surat kredit perumahan yang berbunga rendah pada tahun 2001 sampai dengan 2006 menyebabkan ledakan permintaan di pasar perumahan (boom in the housing market). Bank sentral AS mematok bunga rendah pada tahun 2001-2006 dalam usaha untuk mengantisipasi kelesuan investasi karena dampak runtuhnya saham-saham teknologi (burst of internet bubble) pada Maret 2000.

Persoalannya sekarang adalah bagaimana kita belajar dari krisis di As ini?

Dalam Islam, uang adalah uang, uang bukan barang yang bisa dijualbelikan. Seperti halnya bukti atas kepemilikan uang dalam bentuk hutang atau surat utang tidak dapat di perjualbelikan dengan mensekuritasikan dalam beberapa efek. Utang telah menjadi komoditi yang diperjualbelikan sehingga nilai utang yang awal mula didasarkan atas nilai asset, perumahan, menjadi berlipat ganda. Pasar kapitalis menciptakan uang yang tidak di back up aset riil sehingga menjadikan nilai uang menjadi semu.

Uang adalah alat tukar yang tidak bisa berperan sebagai obyek transaksi. Kalau uang sebagai obyek transaksi maka untuk mendapatkan uang membutuhkan kompensasi berupa keuntungan atau yang dikenal "bunga". Dalam praktek keuangan Islam "tidak mengenal bunga tetapi profit' margin, sewa dan upah". Sedangkan yang disebut profit adalah harga atas barang yang diperdagangkan antara konsumen dan pihak lembaga keuangan dengan obyeknya yakni barang, bukan uang. Konsumen yang mengajukan pembiayaan di lembaga keuangan

${ }^{30}$ Buchari Alma (1993). Ajaran Islam Dalam Bisnis. Bandung: CV. Alfabeta 
syari'ah tidak diberi uang tetapi barang yang dibutuhkan. Bahwa sistem keuangan Islam lebih akomodatif dalam memenuhi kebutuhan masyarakat yang mengajukan pembiayaan.

Tindakan investor yang membeli derivative lebih banyak didasarkan atas informasi yang tidak pasti. Investor lebih mengedepankan informasi yang dipengaruhi pasar karena pegangan yang dipergunakan tidak didasarkan atas aset riil. Bila obyek transaksi adalah berbentuk aset riil maka spekulasi dapat diminimalisasi. Namun kalau obyek tidak pasti maka nilai yang dijadikan untuk melakukan transaksi adalah sentimen pasar yang berkembang. Oleh karena itulah Islam mendorong investor untuk mengelola sektor riil dimana obyek yang menjadi transaksi lebih pasti.

Kemajuan yang tidak didasarkan oleh pemenuhan atau kemaslahatan akan kehilangan barokah dalam kehidupan. Apabila pertimbangan ekonomi sudah meninggalkan tujuan syariah (muqasid syariah) maka kesejahteraan (fallah) akan sulit dicapai, sehingga manusia semakin tidak mampu memenuhi kebutuhan sandang, pangan, papan, pendidikan dan kesehatan. ${ }^{31}$

Bahwa kondisi perekonomian global yang diguncang krisis finansial dalam beberapa waktu terakhir tidak juga menemukan solusi yang jelas. Berbagai formula yang diajukan masih diragukan kefektifannya dalam tata ekonomi baru dunia yang bakal terbentuk pasca krisis.

Salah satu sistem yang bisa menjadi altenatif solusi adalah sistem perekonomian berbasis syariah Islam. Sistem perekonomian yang telah mapan bahkan di negara-negara maju bisa menjadi obat untuk menyembuhkan perekonomian dunia yang kini sakit itu.

Event yang bisa diharapkan menjadi test case dari menawarkan ekonomi syariah sebagai bagian dari solusi krisis finansial adalah 5th World Islamic Economic Forum yang akan digelar 2-3 Maret 2009 mendatang. Forum tersebut rencananya akan dihadiri oleh delegasi dari berbagai negara muslim sedunia serta undangan negara non muslim.

Bahkan, Presiden terpilih AS diharapkan bisa turut hadir dalam acara yang rencana akan digelar di Ritz Carlton Pascific Place.

Sofyan Djalil menjelaskan bahwa Co Chairman WIEF bertujuan untuk mengembangkan program-program yang dapat mempromosikan aktivitas bisnis dari dua segmen utama masyarakat muslim yakni; perempuan dan kaum muda. Diharapkan dua segmen ini bisa optimal dan meningkatkan kemampuan kreatif ${ }^{32}$.

Itulah realita yang ada di lapangan, praktek bank Islam pun masih saja terjadi riba. Contoh yang konkrit; adanya bunga yang di hilah (diakali) dengan cara mengenakan biaya administrasi yang tinggi melebihi yang semestinya.

${ }^{31}$ Heri Sudarsono (2008). "Belajar dari Krisis Keuangan Global". UII News, Edisi 66 Th.VI,Oktober ,hh.1-2.

32 Jawa Pos, 30 Januari 2009 


\section{Penutup}

Tentang ayat riba sebenarnya belum diuraikan Nabi secara tuntas dan Beliau wafat tidak lama setelah ayat ini turun. Seperti dikatakan oleh Umar bin Chattab beliau menjadi kalifah: Sesungguhnya Al Qur'an yang terakhir sekali turun ialah ayat tentang riba. Dan Rasulullah saw. Telah wafat, padahal belum seluruhnya beliau terangkan kepada kita. Oleh sebab itu tinggalkanlah apa yang menimbulkan keraguan dalam hati kamu dan pilihlah apa yang tidak menimbulkan keraguan.

Adapun hukum amaliyah yang bisa berubah menurut kondisi dan waktu, Al Qur"an hanya menetapkan prinsip-prinsip umum saja, misalnya yang berhubungan dengan muamalah madiyah atau hukum benda dan perjanjian. Al Qur'an hanya menetapkan prinsip umum berupa cara memperoleh harta adalah jalan halal dan mentasarrufkannya secara yang bermanfaat. Maka ditetapkanlah kehalalan dan kebolehan jual beli dan haramnya riba.

Tidak ada riba yang halal. Semua riba haram, seperti ditegaskan oleh Allah dalam ayat 275 Al Baqarah di atas,Allah menghalalkan jual beli dan mengharamkan riba.

\section{DAFTAR PUSTAKA}

Abd. Al Haq Humaisy dan Al Husein Syawat (2001). Fiqh Al 'Uqud Al-Maliyyah. Amman (Jordan): Dar Al Bayariq.

Abdurrahman, Asmuni (1992). Tanya Jawab Agama II. Suara Muhammadiyah. AB. Gani, Abd. Mumin (1999). Sistem Keuangan dan Pelaksanaannya di Malaysia. Kuala Kumpur: Jabatan Kemajuan Islam Malaysia.

Al Asqalani, Ibn Hajar (1994). Bulugul Al Maram Min Adillat Al Ahkam. Bandung: Gema Risalah Press.

Alma, Buchari (1993). Ajaran Islam Dalam Bisnis. Bandung: CV. Alfabeta.

Al Mushlih, Abdullah (2004). Fiqh Ekonomi Keuangan Islam. Yogyakarta: Darul Haq.

Keputusan Tarjih Muhammadiyah (1989), Malang.

Mannan, Muhammad Abdul (1993). Ekonomi Islam Teori dan Praktek. Yogyakarta: Dana Bakti Wakaf.

Republika (2007).

Yayasan Penyelenggara Penerjemah Al Qur'an, Al Qur'an Al Karim dan Terjemahannya (1995), Semarang: PT. Karya Toha Putra. Departemen Agama RI.

Zuhaili, Wahbah (1997). Al Fiqh Al Islami Wa Adillatuluh, juz 3, cet.4.

Beirit: Dar Al Fitr. 